\title{
RUSSIAN GEOLOGIC REPOSITORY TECHNICAL PAPERS AND REPORTS
}

\author{
Leslie J. Jardine
}

February 18, 2002

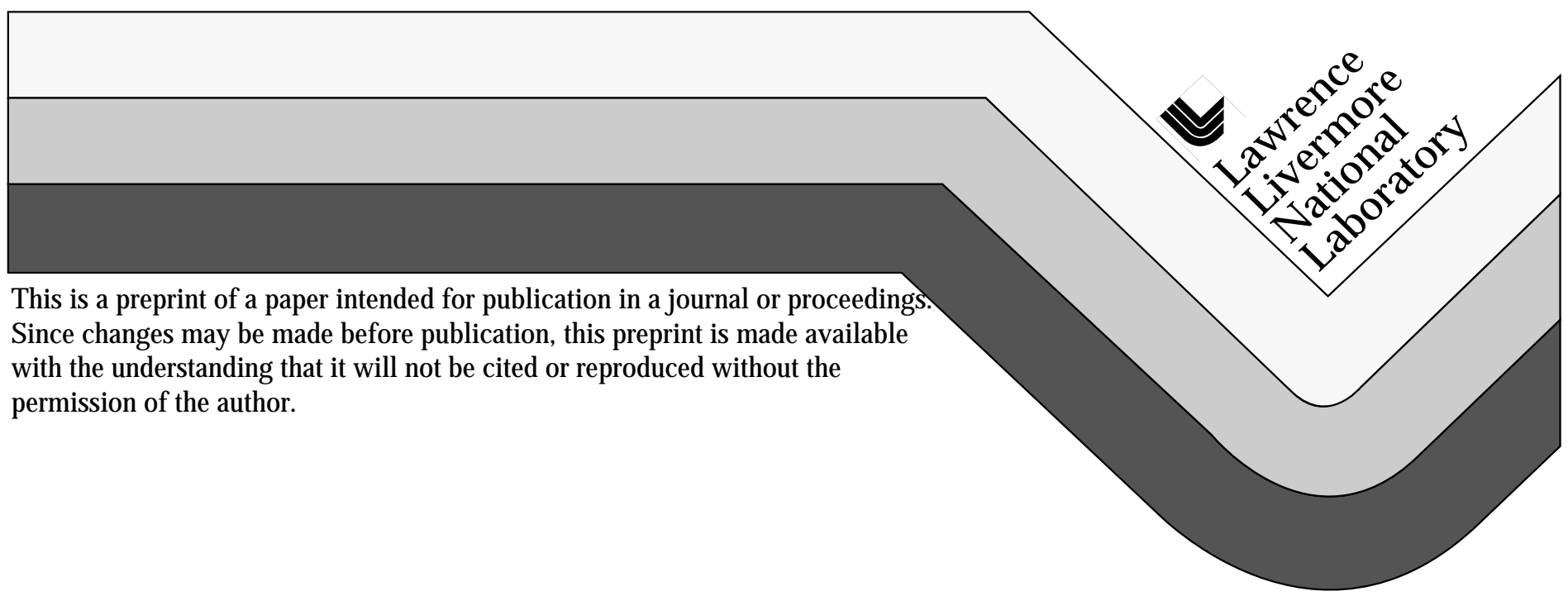




\section{DISCLAIMER}

This document was prepared as an account of work sponsored by an agency of the United States Government. Neither the United States Government nor the University of California nor any of their employees, makes any warranty, express or implied, or assumes any legal liability or responsibility for the accuracy, completeness, or usefulness of any information, apparatus, product, or process disclosed, or represents that its use would not infringe privately owned rights. Reference herein to any specific commercial product, process, or service by trade name, trademark, manufacturer, or otherwise, does not necessarily constitute or imply its endorsement, recommendation, or favoring by the United States Government or the University of California. The views and opinions of authors expressed herein do not necessarily state or reflect those of the United States Government or the University of California, and shall not be used for advertising or product endorsement purposes.

This is a preprint of a paper intended for publication in a journal or proceedings. Since changes may be made before publication, this preprint is made available with the understanding that it will not be cited or reproduced without the permission of the author.

This work was performed under the auspices of the United States Department of Energy by the University of California, Lawrence Livermore National Laboratory under contract No. W-7405-Eng-48.

This report has been reproduced directly from the best available copy.

Available electronically at http://www.doc.gov/bridge

Available for a processing fee to U.S. Department of Energy

And its contractors in paper from

U.S. Department of Energy

Office of Scientific and Technical Information

P.O. Box 62

Oak Ridge, TN 37831-0062

Telephone: (865) 576-8401

Facsimile: (865) 576-5728

E-mail: reports@adonis.osti.gov

Available for the sale to the public from

U.S. Department of Commerce

National Technical Information Service

5285 Port Royal Road

Springfield, VA 22161

Telephone: (800) 553-6847

Facsimile: (703) 605-6900

E-mail: orders@ntis.fedworld.gov

Online ordering: http://www.ntis.gov/ordering.htm

Or

Lawrence Livermore National Laboratory

Technical Information Department's Digital Library

http://www.llnl.gov/tid/Library.html 


\section{CONTENTS}

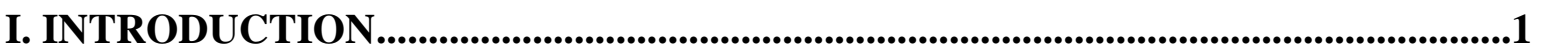

\section{TECHNICAL PAPERS AND REPORTS INVOLVING RF GEOLOGIC} DISPOSAL, OVERVIEW, POLICY AND PLANNING TOPICS .....................................4
A. Summary and Overview 4
B. Additional Background 5

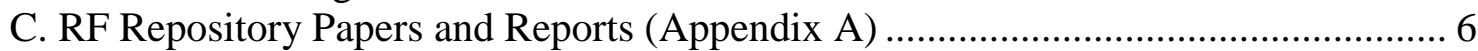

\section{TECHNICAL PAPERS AND REPORTS INVOLVING RF GEOLOGIC} DISPOSAL ACTIVITIES FOR THE KRASNOYARSK-26 SITE 7

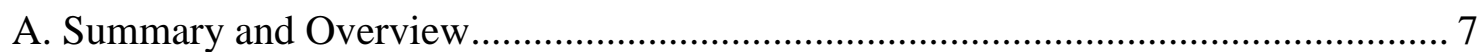

B. K-26 Technical Papers and Reports (Appendix B) ................................................... 9

IV. TECHNICAL PAPERS AND REPORTS INVOLVING RF GEOLOGIC DISPOSAL ACTIVITIES FOR THE MAYAK SITE .........................................................11

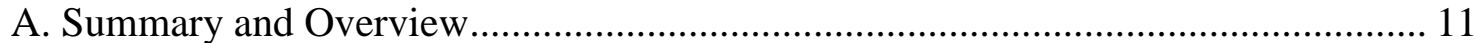

B. Mayak Technical Papers and Reports (Appendix C) ............................................... 14

V. FINAL REMARKS .....................................................................................................15

VI. REFERENCES ...................................................................................................16

APPENDICES...........................................................................................................................18

APPENDix A: OVERVIEW, POLICY ANd Planning DOCUMENTS FOR RF

REPOSITORY

APPENDIX B: K-26 TECHNICAL PAPERS AND REPORTS

APPENDIX C: MAYAK TECHNICAL PAPERS AND REPORTS 


\section{INTRODUCTION}

Lawrence Livermore National Laboratory (LLNL) has been actively and continuously engaged in Russian geologic disposal activities since 1995. The first joint US-Russian meeting on Disposition of Excess Weapons Plutonium was held in January 1995 at Los Alamos National Laboratory (LANL). The meeting resulted in the appointment of Dr. L. J. Jardine from LLNL and Dr. T. A. Gupalo from the All-Russian Research and Design Institute of Production Engineering (VNIPIPT) as the US-Russian Federation (RF) joint co-chairs for geologic disposal of plutonium-containing materials, respectively. The initial joint studies focused on the geologic disposal of plutonium-containing materials and immobilized plutonium waste forms. These studies started in 1995, and continue in 2002. The first joint work of LLNL and VNIPIPT was documented in the October 1996 Paris P8 Nuclear Experts Meeting [1].

These initial US-RF cooperative studies led to the definition of Russian geologic repository activities of mutual interest. As a result, a series of four contracts between LLNL and VNIPIPT were issued, starting in 1996 and continuing through 2001. The contracts (UTA-96-0331, \$100K; B338273, \$150K; B501120, \$160K; B512134: \$92K) studied experimentally various geologic disposal aspects of plutonium migration and other radionuclide migration and engineered barrier materials, and developed computer models. The most recent experimental contract work, B512134, performed radionuclide and plutonium migration tests in underground rocks on a scale of approximately $1 \mathrm{~m}^{3}$ at the underground RF Mining Chemical Combine (MCC) Krasnoyarsk-26 (K-26) facilities, using actual plutonium-containing glasses with fission products as sources of radionuclides from a simulated engineered barrier system [2].

In late 2000, and in 2001, Drs. Jardine and Gupalo identified the need to have a current and updated plan for geologic disposal of plutonium-containing materials in the RF. Subsequently, an LLNL contract with VNIPIPT, B512155, produced an integrated plan of how to develop a geologic repository at the two sites near K-26 and Mayak [3]. A separate LLNL contract with the V. G. Khlopin Radium Institute (KRI), B512154, developed geotechnical portions of the plan for the K-26 site [4]. These two final reports were approved by Minatom as LLNL deliverables; they represent a current approved Minatom plan for developing geologic repositories in Russia at these two sites [3].

In addition to the contracts with VNIPIPT and KRI, LLNL negotiated and completed contracts B347676, B506210, and B506233 with the MCC K-26 site and contracts B506201 and B506208 with the Mayak site and the All-Russian Design Research Institute of Complex Power Technology (VNIPIET) for engineering studies that developed geologic disposal concepts for their immobilized plutonium-containing materials. VNIPIET provided geologic disposal expertise to these contracts. The engineering reports focused on immobilization of plutoniumcontaining sludges but also addressed preliminary geologic disposal concepts, including costs, for the geologic disposal of immobilized plutonium-containing waste forms [5-8].

In addition to these joint US-Russian plutonium disposition studies funded by LLNL with US Department of Energy (DOE) funds, LLNL participated directly over the years in four key International Science and Technology Center (ISTC) projects that focused on Russian geologic disposal activities near the K-26 site. The first was ISTC Project 307B: L. Jardine assisted T. Gupalo, VNIPIPT, to develop the initial proposal and to secure ISTC funding in 1997, and he 
served as the US Collaborator. The final project report for Project 307B documents over 40 years of heat effects from underground nuclear reactor steam generators and other heated components on the gneiss rocks of the underground MCC K-26 facility. In addition to heat effects, the project assessed thermal-mechanical, hydrology, and geochemistry effects in the gneiss rock masses [9]. L. Jardine also served as the US Collaborator for ISTC Project 255 and ISTC Project 1491. These two projects, managed by E. B. Anderson, KRI, developed various site characterization activities for the repository site near K-26 for the Ninzenkansky granite massif [10,11]. In 2001, L. Jardine assisted DOE-RW and VNIPIPT to define and fund-a new DOE-RW, ISTC Partner Project 2377 in 2002. Project 2377 will implement portions of the current Minatom plan prepared by VNIPIPT in 2001 for the K-26 site, which will, after three years, provide valuable data for updating and revising the Minatom plan for the K-26 site [12].

LLNL is also assisting DOE-RW to manage a small effort by the Institute of Ore Deposits Geology, Petrology, Mineralogy and Geochemistry-Russian Academy of Sciences (IGEM-RAS) to develop geotechnical inputs to a scientific plan for developing the granite massif site K-26. The IGEM-RAS Plan will provide scientific inputs to the new ISTC Project 2377 activities. Similarly, the engineering studies performed by VNIPIET, VNIPIPT, and MCC for geologic disposal for immobilized plutonium forms will be valuable inputs to ISTC Project 2377 [5-8].

In summary, LLNL has been actively and continously involved in various ways since 1995 in developing and participating in the current Russian geologic disposal program activities near the Mayak and MCC K-26 sites. Figure 1 illustrates how these various LLNL activities have been integrated, coordinated, and focused on developing geologic disposal in Russia. The various LLNL contracts are shown in the figure with the specific LLNL contract number. Reference 13 provides a summary of the status in 2000 of the past Russian repository program activities for the K-26 and Mayak sites.

Because of this unique continuous and direct participation in the RF geologic disposal program activities, LLNL has either obtained or generated numerous technical papers and reports documenting various aspects of the RF geologic repository activities for the two sites near the Minatom industrial sites at Mayak and K-26. As a result, LLNL decided to collect these unique documents into one referenceable set and generated this report.

This report collects these technical papers, technical reports, plans, and proposals for developing various aspects of geologic repository sites in Russia. Most, but not all, of these have been prepared by LLNL staff, by Russian experts in collaboration with LLNL staff, or by Russian organizations under an LLNL contract using DOE funds. The purpose of this report is to put into one LLNL document the collection of current papers and reports in order to summarize and document the status of the Russian geologic repository programs for which LLNL has been directly and continuously involved since 1995 . This report will be useful to many interested in the RF geologic disposal activities. The collection demonstrates the seriousness and depth of the RF institutes and LLNL activities in recent years to develop a RF geologic repository program, even with very limited funds.

This report is organized into five sections. After the Introduction, Section II provides a listing of technical papers and reports involving RF geologic repository topics of an overview, policy, or planning nature. The next two sections, III and IV, provide a listing of technical papers and reports for the specific sites near K-26 and Mayak, respectively. A brief summary and background is provided in Sections II, III, and IV preceding the list of papers and reports that 
pertain to each section. Finally, Section V provides some final comments regarding the LLNL perspective of the RF geologic disposal activities and prospects.

The appendices to this document contain the full text of all the RF geologic disposal papers and reports listed in Sections II-IV. The documents in Appendix A are overview, policy, and planning documents. Appendix B contains the K-26 site-specific documents, and Appendix C contains the Mayak site-specific documents.

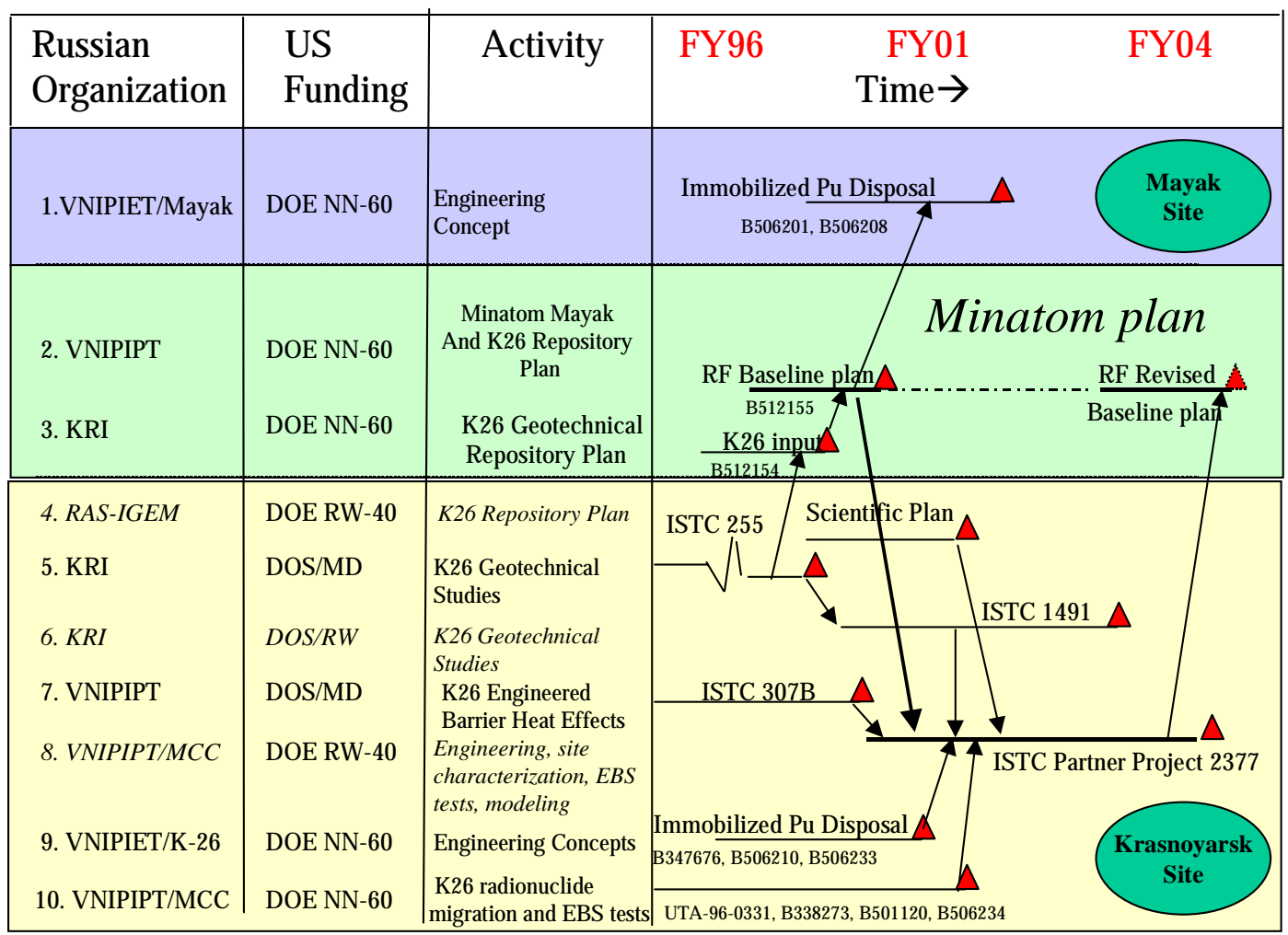

Figure 1. LLNL is actively engaged in RF geologic disposal activities near the Mayak and K-26 industrial sites. 


\section{TECHNICAL PAPERS AND REPORTS INVOLVING RF GEOLOGIC DISPOSAL, OVERVIEW, POLICY AND PLANNING TOPICS}

\section{A. Summary and Overview}

The current Russian program for geologic disposal uses a regional approach to select three primary sites for geologic disposal of high-level wastes (HLW) and other radioactive wastes (RW) from civil and military programs in Russia as well as Pu-containing wastes from future excess weapons plutonium disposition activities. The three potential RF repositories are to be located at Novaya Zemlya, PO Mayak in the eastern Urals, and near the Mining and Chemical Combine (MCC) at Krasnoyarsk-26 (K-26) in Middle Siberia. Only the Mayak and K-26 sites are discussed further as these sites are for high level radioactive wastes and plutoniumcontaining wastes.

The Minatom industrial production enterprises have worked for many years together with Minatom scientific and design institutions, local geologic agencies and the Russian Academy of Sciences in Moscow, St. Petersburg, and elsewhere to develop various methodologies and concepts for site characterization and selection. At present, the two leading institutes responsible for various aspects of repository development at Minatom sites are VNIPIPT in Moscow and KRI in St. Petersburg. Should development of an RF geologic repository actually begin, many other RF organizations would be involved in specific activities using their expertise.

The current reference geologic repository design concept for Mayak uses underground boreholes for emplacement of solid waste at depths of $1000 \mathrm{~m}$. The reference repository concept for MCC emplaces solid and high-level solidified wastes in a granite massif with the specific design decision of boreholes vs. mined cavities still to be made. At Mayak and K-26, initial and limited site characterizations have been performed and documented by scientists and engineers of many Russian organizations. Specific areas at these two potential repository sites for defense program wastes have been screened and selected for detailed characterization to confirm their acceptability should funds be made available to proceed with their development. Official site approvals can be made only after site selection activities have been properly substantiated and documented according to RF state standards (GOST). This work has not yet been performed. Once funds are allocated, implementation of current RF plans to characterize and select specific sites in Russia can proceed. VNIPIPT has been selected by Minatom as their lead institute for development of geologic disposal in the RF.

Similarly, licensed design organizations are available and waiting for funding allocations to develop the conceptual designs and perform the required technical and economic feasibility studies of engineered barriers and repository options for geologic disposal. This activity would be done in parallel with any new site-specific characterization activities. Sufficient site characterizations, including core retrievals from proposed sites, have been performed to start the engineering process but the designs have not been started due to a lack of funding. Preliminary plans exist for developing and constructing underground laboratories at Mayak and K-26 sites to validate site-specific characteristics for the natural barriers and for the proposed engineering barrier systems for emplaced radioactive wastes. The most critical item is the lack of any 
allocation of funding to mobilize the Russian technical and scientific community, which is well prepared - after decades of completed and documented work - to develop a Russian geologic repository.

\section{B. Additional Background}

Large volumes of radioactive waste have been accumulated in Russia from defense-related and civil power engineering production programs and research in fissionable nuclear materials. The HLW portion is composed of long-lived radionuclides including the actinide group whose radiobiological hazard will last for many millennia. Many sources of these wastes, but not all, require treatment to make solid forms acceptable for geologic disposal. New activities at Mayak and $\mathrm{MCC}$ are being planned in collaboration with LLNL to treat and immobilize excess weapons $\mathrm{Pu}$-containing materials and plutonium-containing wastes from weapons plutonium conversion and MOX fabrication for storage and geologic disposal. The separation and isolation of these ecologically harmful wastes from the human habitat for a length of time measured in geological epochs is necessary to protect human health and the environment.

At the MCC K-26 site, the Russian practice has been to reprocess spent nuclear fuel to recover weapons plutonium, isolate defense program liquid low and intermediate level wastes (LLW, ILW) in deep water-bearing horizons by deep borehole injection, and place solid and solidified ILW and LLW in subsurface repositories [14]. About $6000 \mathrm{~m}^{3}$ of radioactive sludges contain plutonium, uranium, chemicals, and fission products not suitable for borehole disposal. These sludges contain about 1200 to $1800 \mathrm{~kg}$ of weapons plutonium and are being stored at the MCC K-26 site in underground tanks. [25,26] Safe processing or reprocessing HLW on the basis of waste fractionation with recovery of cesium-strontium and actinide fractions [15] and their eventual solidification and separate burial, taking into account the different required safety precautions [16], may become a more economically feasible and technologically efficient alternative in the future but is not seriously being considered currently by the MCC.

At the Mayak site, an alternative approach to underground disposal of HLW is based on the application of new Russian technologies, such as immobilization in a glass or ceramic matrix and perhaps the future fractionation of liquid HLW with separation of radionuclide fractions that vary in half life, toxicity, heating rate, specific radioactivity, and physical volumes. The synthesis of highly stable mineral and glass matrices to immobilize these separated fractions and, after storage, their subsequent selective burial at various depths and geological conditions is an important part of the Mayak research investigations in progress.

At present, liquid LLW at Mayak is prepared for disposal by solidification in cement matrices. Once short-lived LLW is conditioned, it can be disposed of in subsurface ferroconcrete repositories, constructed in clays. This technology has been already elaborated and is now being used in Russia [17]. New LLW and ILW disposal sites will likely be constructed near sources of production and temporary storage locations. HLW is incorporated at Mayak into phosphate glass-like compositions in a ceramic melter and then stored in a surface building. Mayak also, like the MCC K-26 site, has radioactive sludges containing about 1000 to $1500 \mathrm{~kg}$ of weapons plutonium in storage in surface tanks. These sludges will require treatment for long term storage and geologic disposal.[25,26] 


\section{RF Repository Papers and Reports (Appendix A)}

Additional general information of a policy, planning or overview nature about the Russian Geologic Disposal program may be found in the following papers and reports, which are reprinted in full as Appendix A of this document. The documents that address specific site activities near K-26 and Mayak are reprinted in Appendices B and C, respectively.

A.1 L. J. Jardine, T. A. Gupalo, Geologic Repository Plan for Disposal of Plutonium-Containing and Other Radioactive Materials in Russian Industrial Sites, (B512155), UCRL-CR-146982, Lawrence Livermore National Laboratory, Livermore, CA, February 2002.

A.2. $\quad$ L. J. Jardine, T. A. Gupalo, et al., US-Russian Joint Study Report of Geologic Disposition Options for Excess Plutonium from Dismantled Nuclear Weapons (Combined Report), September 30, 1996 (UCRL-ID-124711); Joint United States Russian Plutonium Disposition Study Summary Report, September 1996.

A.3 L. J. Jardine, Framing a Bilateral U.S.-Russian Geologic Repository Initiative, Lawrence Livermore National Laboratory, Livermore, CA, UCRL-ID-131801, 1998.

A.4 T. A. Gupalo, E. B. Anderson and L. J. Jardine, Status of Geologic Disposal and Isolation in Russia for PlutoniumContaining Wastes of Military Programs, DISTEC 2000 Conference, Berlin, Germany, September 4-6, 2000 (UCRL-JC138202).

A.5 L. J. Jardine, C. F. Smith, W. G. Halsey, Vision and Framework for Technical and Management Support to Facilitate Foreign Spent Fuel Storage and Geologic Disposal in Russia, UCRL-ID-134762, July, 1999.

A.6 L. J. Jardine., W. G. Halsey, and C.F. Smith, "Foreign Spent Fuel Storage and Geologic Disposal in Russia: A Technical Path Forward," Waste Management 2000, Tucson, AZ, Feb. 27, 2000, UCRL-VG-137265, 2000.

A.7 W. G. Halsey, L. J. Jardine and C. E. Walter, "Disposition of Plutonium in Deep Boreholes," Proceedings of NATO International Scientific Exchange Program, Advanced Research Workshop on Disposal of Weapons Plutonium - Approaches and Prospects, St. Petersburg, Russia, May 14-17, 1995, Lawrence Livermore National Laboratory, UCRL-JC-120995, R1, 1995.

A.8 T. A. Gupalo, V. P. Beygul, R. T. Islamov, "Safety Problems for Long-term Underground Storage and Final Disposal of Nuclear Materials," Advanced Research Workshop: Nuclear Materials Safety, June 8-10, 1998, St. Petersburg, Russia, Lawrence Livermore National Laboratory, UCRL-JC-132632, p. 73, January 4, 1999.

A.9 W. G. Halsey and L. J. Jardine, Russian Spent Fuel Storage and Transportation to Support Termination of Civil Power Reactor Fuel Reprocessing at RT-1, A Technology Map, Lawrence Livermore National Laboratory, UCRL-ID-142749-DR, March 5, 2001. 


\section{TECHNICAL PAPERS AND REPORTS INVOLVING RF GEOLOGIC DISPOSAL ACTIVITIES FOR THE KRASNOYARSK-26 SITE}

\section{A. Summary and Overview}

For several years, NPO “Khlopin Radium Institute" together with Minatom, Ministry of Sciences, Russian Academy of Sciences, Krasnoyarsk regional institutes and agencies have carried out comprehensive scientific research studies of geologic disposal for a Russian regional repository near K-26. The work was carried out by stages, with a consistent increase in the range and detail of investigations. A comprehensive analysis of geologic and geophysical data was made to discover the most homogenous and least dislocated areas.

Initially, about twenty areas among the ancient gneiss mass and granitoid rock masses of the MCC territory were selected and evaluated by specifically developed summary criteria, including adequate size, minimum permeability for the radionuclides, absence of considerable mineral resources, and ability to retain its protective properties for the required period of time [18]. The Nizhnekansky granitoid rock mass was considered to be the best of several prospective geologic formations (e.g., slow uplift of $\sim 1 \mathrm{~mm} / \mathrm{y}$, low seismic activity, comparatively uniform, large granitoid blocks, relatively limited economic and industrial activity, sparsely populated, and 10$30 \mathrm{~km}$ from MCC). This is one of the largest granitoid rock masses in Middle Siberia (Fig. 2). It has an area of over $1500 \mathrm{~km}^{2}$ and is 4-6 km deep. Its northwest boundary is only $3 \mathrm{~km}$ away from MCC. A number of studies on a scale of 1:100,000-1:25,000 were conducted by different groups of researchers for the northern part of the Nizhnekansky massif and its Archean-Proterozoic setting. Cross and longitudinal geological sections plotted from gravimetric survey data on a scale of 1:200,000 show that the Nizhnekansky massif has the shape of a bowl 5 to $6 \mathrm{~km}$ in depth.

Ultimately, two sites were identified, Itatskiy and Kamennyi, where subsequent detailed explorations were made (Fig. 3). The two sites cover an area of $7 \mathrm{~km}^{2}$ each and are located 25 to $30 \mathrm{~km}$ away from MCC.

Laverov et al. [19] studied the migration of water solutions through the rock mass, which is the main mechanism of radionuclide movement. They calculated a hydraulic conductivity of about $10^{-7} \mathrm{~m} / \mathrm{d}$ (i.e., approximately $0.1-0.01 \mathrm{~mm} / \mathrm{y}$ ) for representative granitoid samples. Such a value is close to that required for construction of the repository $\left(10^{-8}-10^{-7} \mathrm{~m} / \mathrm{d}\right)$.

Laverov et al. also investigated other factors such as solubility, permeability, and retention, and conclude that the integrated permeability of the geological environment of the repository will depend only on the presence of permeable fractures. Also, incorporation of radionuclides via diffusion and their retention by sorption significantly limit the range of migration of especially long-lived alpha-emitting radionuclides under the influence of migrating water.

Although it appears the Kamennyi site is more promising, data are needed on structural characteristics, mineralogical-petrological composition of rocks, characteristics of underground waters, properties of the rocks as barriers to radionuclide migration to the biosphere, and parameters of zones of active fracture to determine whether either or both sites are suitable for 


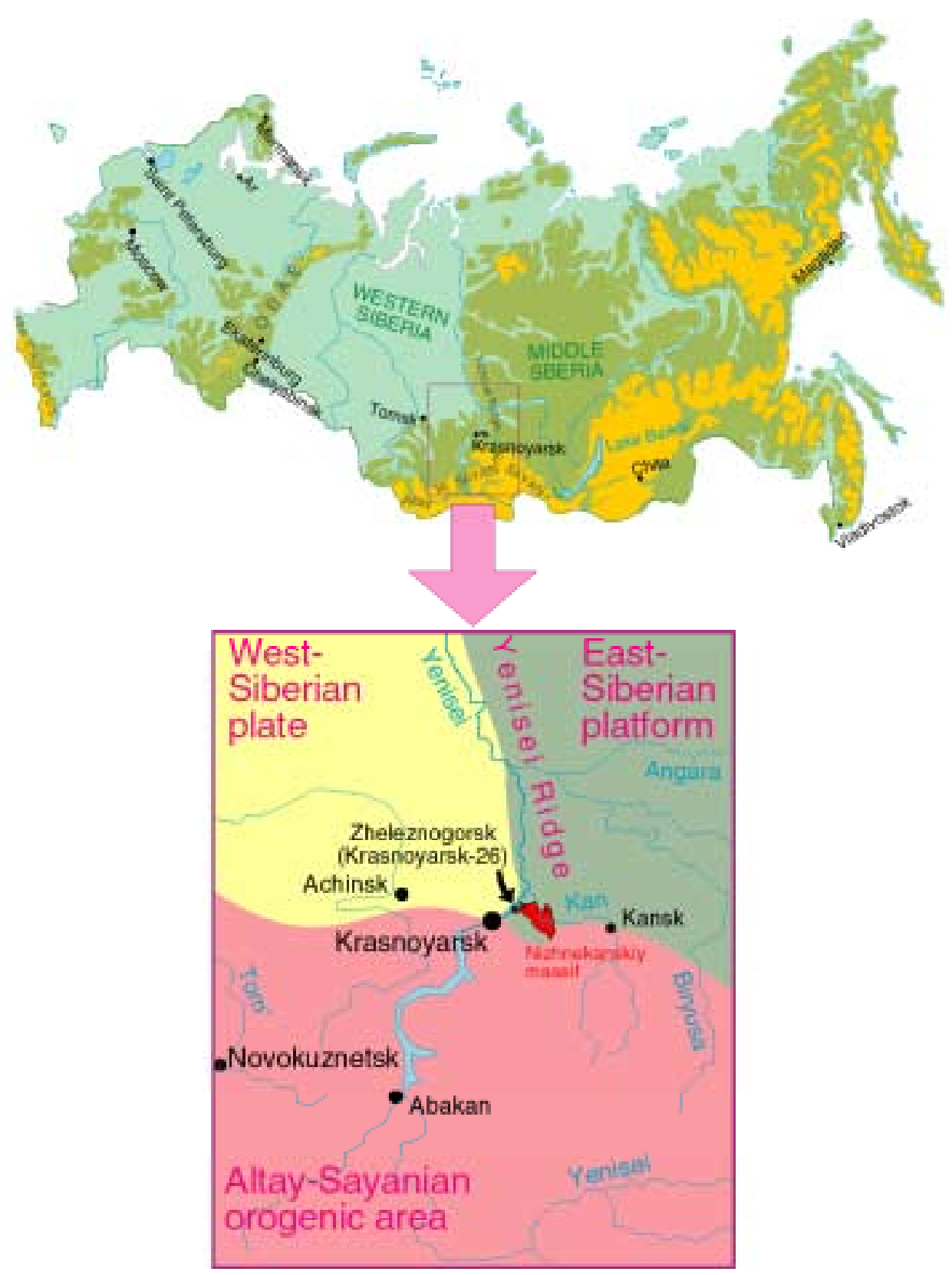

Figure 2. Location and global geological structure map of K-26 territory shows Nizhnekansky immediately southeast of K-26 (see arrow) [18].

detailed geological exploration. Still to be done are an engineering-geological estimate of optimum location, a structural design for future underground storage, and substantiation of site suitability.

The recently issued RF geologic repository plan [3], also see Report A.1, Appendix A, provides specific plans of how the development of the MCC K-26 site should proceed once funds are available. Reports B.3 and B.4, Appendix B, provide details of how portions of the full plan are being undertaken. 


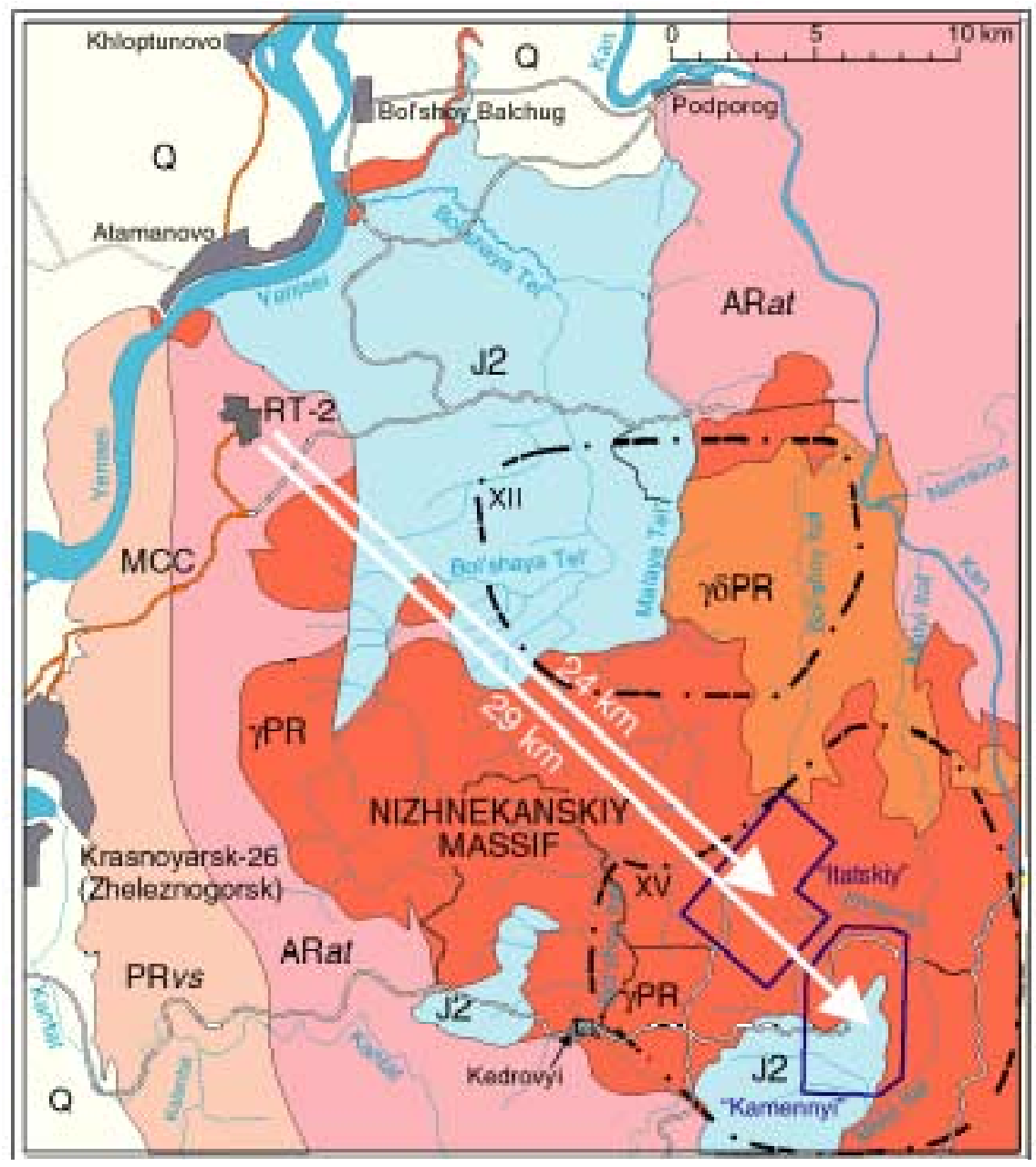

Figure 3. Two areas within the Nizhnekansky massif, XII and XV, (boundaries shown as dashed lines) were selected on the basis of geophysical data analysis and tectonic structure analysis at 1:200,000. The specific sites, Itatskiy and Kamennyi, were identified using field reconnaissance work after detailed tectonic structure analysis at 1:50,000.

\section{B. K-26 Technical Papers and Reports (Appendix B)}

Additional information about potential repository sites near K-26 may be found in the following papers and reports, which are reprinted in full as Appendix B of this document:

B.1 E. B. Anderson, Investigations in the field of long-lived radioactive waste final disposal in geological formations : an assessment of the possibility of the RT-2 plant radioactive waste disposal in rocks of the Yenisey Ridge, Project 255 Final Technical Report of ISTC 255-95, RP-226, January 2002.

B.2 T. A. Gupalo, Development of quantitative criteria for suitability of rock mass for safe long-term storage of waste from weapons-grade plutonium production, illustrated by Krasnoyarsk Mining Chemical Combine: Summary Technical Report 307B, (RP-227), Feb. 28. 2001.

B.3 E. B. Anderson, Geological-Geochemical and Geophysical Research of Granitoids of the Nizhnekanskiy Massiffor a Choice of Sites for Underground Repository of High-Level Radioactive Waste of Russian Industrial Sites: Mining-Chemical Combine (MCC), "Mayak" Production Association, Siberian Chemical Combine (Tomsk), Work Plan 1491, ISTC Project Proposal \#1491, RP-229, January 2002. 
B.4 T. A. Gupalo, Development of A Comprehensive Plan for Scientific Research, Exploration, and Design: Creation of An Underground Radioactive Waste Isolation Facility at The Nizhnekansky Rock Massif, ISTC Project Proposal \#2377 Section 1. Concurrence and Commitments, RP-228, January 2002.

B.5 E. B. Anderson, Plan for Geologic Repositories for Disposal of Immobilized Plutonium-containing Materials and Other Radioactive Materials at Russian Industrial Sites, Final Report RP-188 (B512154), August, 2001.

B.6 T. A. Gupalo, Large-Scale Laboratory and In-Situ Investigations of Pu and U Radionuclides Migration in the MultiBarrier System for Underground Isolation of the MCC Vitrified Waste, Final Report, RP-215, (B512134), December, 2001.

B.7 T.A. Gupalo, V. P. Beygul, VNIPIPT, "Description of Engineering Solutions for Safe Underground Isolation of MCC Immobilized Sludges for JOI," Immobilization of Excess Weapons Plutonium in Russia: A Review of LLNL Contract Work: UCRL-JC-143846, pp. 75-80, 2001.

B.8 V. S. Gupalo, VNIPIPT, "Results of Studies on Mining and Geological Conditions and Mathematical Modeling of Geomechanical Processes in Underground Storage Facilities for MCC Immobilized Sludges from KMCC," Immobilization of Excess Weapons Plutonium in Russia: A Review of LLNL Contract Work: UCRL-JC-143846, pp. 81-90, 2001.

B.9 T.A. Gupalo, V. P. Beygul, VNIPIPT; K. G. Kudinov, MCC; L. J. Jardine, LLNL, "General Concept and Content of VNIPIPT Works on Substantiation of Geological Isolation of Pu-containing Immobilized Waste," Immobilization of Excess Weapons Plutonium in Russia: A Review of LLNL Contract Work: UCRL-JC-143846, pp. 235-238, 2001.

B.10 T.A. Gupalo, V. P. Beygul, S. L. Speshilov, VNIPIPT; A. A. Tretyakov, S. A. Manakov, KMCC, "Investigation of Uranium and Plutonium Migration in the Multi-barrier System for Underground Isolation of Vitrified Wastes from KMCC," Immobilization of Excess Weapons Plutonium in Russia: A Review of LLNL Contract Work: UCRL-JC-143846, pp. 239-246, 2001.

B.11 E. B. Anderson, V. G. Savonenkov, S. S. Shabalev, E. F. Lyubtseva, Yu. M. Rogozin, KRI, "Site Selection for HLW Geological Disposal at the Nizhnekansky Granitoid Massif," Immobilization of Excess Weapons Plutonium in Russia: A Review of LLNL Contract Work: UCRL-JC-143846, pp. 247-250, 2001

B.12 T.A. Gupalo, A. N. Titkov, VNIPIPT, "Sequence of Works Aimed at Selection of a Site for Plutonium-containing Waste Disposal at Nizhnekansky Massif," Immobilization of Excess Weapons Plutonium in Russia: A Review of LLNL Contract Work: UCRL-JC-143846, pp. 251-252, 2001.

B.13 T.A. Gupalo, V. L. Milovidov, VNIPIPT, "Preliminary Substantiation of Site Selection in Nizhnekansky Massif for Underground Disposal of MCC Pu-containing Wastes by Standards for RW Underground Storage Facility Designing and Construction," Immobilization of Excess Weapons Plutonium in Russia: A Review of LLNL Contract Work: UCRL-JC-143846, pp. 253-257, 2001.

B.14 T. A. Gupalo, VNIPIPT, "Summary of Plutonium Sorption on Rocks and Materials of Destruction of Engineered Barriers at Normal Pressure and Elevated Temperature [UTA-331]," Excess Weapons Plutonium Immobilization in Russia: A Review of LLNL Contract Work, Lawrence Livermore National Laboratory, Livermore, CA, UCRL-ID-138361, pp. 197-200, 2000 .

B.15 T. A. Gupalo, VNIPIPT, "Summary of Plutonium Sorption-Desorption on Rock Samples at Elevated Pressure and Temperature [B338273]," Excess Weapons Plutonium Immobilization in Russia: A Review of LLNL Contract Work, Lawrence Livermore National Laboratory, Livermore, CA, UCRL-ID-138361, pp. 201-206, 2000.

B.16 V. Beygul, VNIPIPT, "Comparison of K-26 Glass Properties and Plutonium Sorption on Hard Rock Cores at Elevated Temperature and Pressure [B501120]," Excess Weapons Plutonium Immobilization in Russia: A Review of LLNL Contract Work, Lawrence Livermore National Laboratory, Livermore, CA, UCRL-ID-138361, pp. 207-214, 2000.

B.17 E. Zakharova, RAS, "Laboratory Studies on the Behavior of Plutonium in the Solidified Radioactive Waste Repositories Located in the Low Fractured Rock Masses [B338272, B501120],” Excess Weapons Plutonium Immobilization in Russia: A Review of LLNL Contract Work, Lawrence Livermore National Laboratory, Livermore, CA, UCRL-ID-138361, pp. 215-227, 2000. 


\section{TECHNICAL PAPERS AND REPORTS INVOLVING RF GEOLOGIC DISPOSAL ACTIVITIES FOR THE MAYAK SITE}

\section{A. Summary and Overview}

Mayak was founded in 1948. Prior to 1986, it produced weapons plutonium, and in 1976, began processing civil spent nuclear fuel in radiochemical plant RT-1. Its accumulated and production radioactive HLW are solidified to glass-like alumo-phosphatic matrices. In the near future, all RW types may be separated into Cs-Sr and actinide fractions but this is not being done today [20,21]. The repository design concept for Mayak emplaces solid waste at depths of over $600 \mathrm{~m}$ in porphyrites in underground boreholes. Large-scale studies carried out at Mayak by VNIPIPT since the late 1950s include experimental boreholes 300 to $1200 \mathrm{~m}$ deep; a complex of geologic and geophysical studies; petrophysical, thermophysical, and hydrogeologic investigations; and determinations of heat and mass transfer conditions of the volcanogenous rock mass at $1200 \mathrm{~m}$ $[22,23]$. Designs for an underground laboratory and repositories using shaft and borehole disposal were based on these studies; however, further surveys and site investigations were halted in the 1980s due to lack of financing.

At the beginning of the 1990s, IGEM-RAS, geologic agencies in Ekaterinburg, and others became involved in the study of disposal of solidified RW. Geologic status was specified by IGEM-RAS in detail, including the mineral and chemical structure, physico-mechanical and geochemical performance of the rock, and seismic probing to determine structure to $5 \mathrm{~km}$ deep. Specialists from the Gidrospetsgeologiya Institute completed a structure contour map of the intact bedrock surface. A helium and radon survey and magnetometer study were done. VNIPIPT studied core samples from deep borehole horizons to estimate structural and tectonic properties, assessed infiltration properties of fracture zones, and quantitatively determined parameters of fractured-vein deep horizons. Based on these Mayak investigations, a number of sites for an underground laboratory are under consideration (Fig. 4). Site characteristics have not yet been confirmed by drilling, geophysical, and filtration studies but draft plans exist to implement tests once funding is allocated. The recently issued RF geologic repository plan [3] (report A.1, Appendix A), provides specific revised plans of how the development of the Mayak site should proceed once funds are available.

Defining the permeability of the entire geologic site thickness is one of the most important factors in selecting repository sites. Structural-morphological methods are also among the most important components in the effort to identify repository sites. Conventional geologicalgeomorphological studies and geodynamic methods are especially important for the location of RW subsurface and medium-depth repositories. They are less important in siting long-lived RW repositories $2-3 \mathrm{~km}$ below the surface because the depth eliminates the effect of such hazardous factors as gradual upward movements of the crust, global climate changes, and catastrophic seismic phenomena (Fig. 5).

The areas occupied by fault zones are considered unsuitable for engineering facilities. Volcanites of basic composition with total thickness near $2 \mathrm{~km}$ are considered to be the most suitable medium for localization of any separated Cs-Sr fraction from RW at Mayak [24]. As a whole, the 


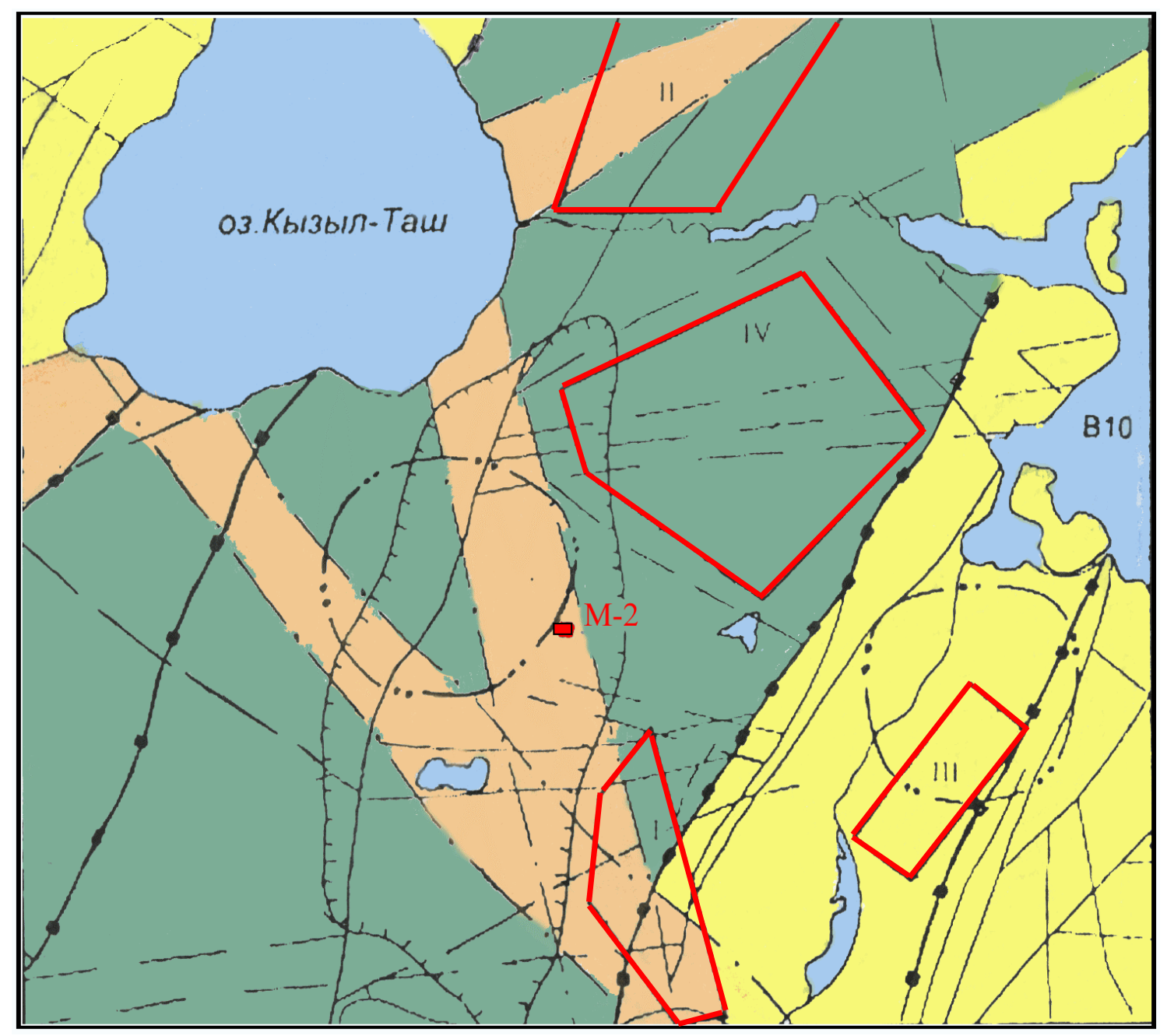

\section{Legend}

Regional breaks

Cutting cracks zones

Ring structures

M-2 "Mars-2" workzone

C.5 Aureole of underground waters pollution

Relatively stable blocks

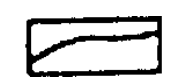

Chipped breaks of all-Ural range

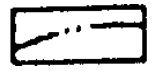

Neotectonical crack zones

1i11 Perspective workzones and their numbers

Ponds

Blocks with increased dynamical tensions

Neotectonical planetary crack zones

Figure 4. Promising sites for geological repositories at PA Mayak. 


\section{Section I-I}
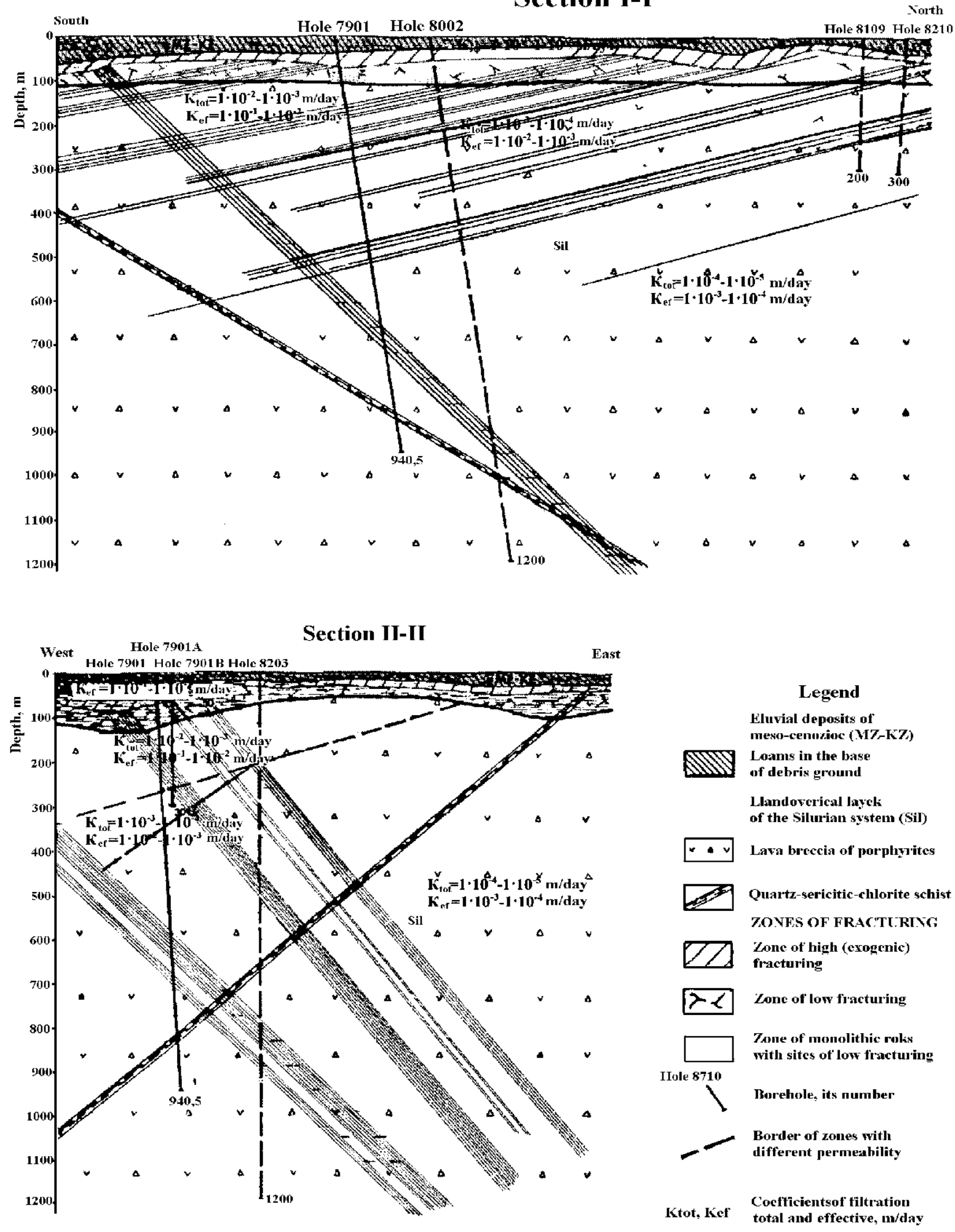

Figure 5. Hydrogeologic profiles of site M-2 at PA Mayak. 
volcanite thickness is made up of andesite-basaltic porphyrites, tuffs and lavas with low (0.2$0.3 \%$ ) effective porosity, high mechanical and thermal stability, and relatively homogenous chemical composition. Porosity in volcanites is quite stable up to $200^{\circ} \mathrm{C}$ and elevated pressure. In the presence of heated water, volcanites' primary minerals (Ca-Na plagioclases, pyroxenes, olivines) are subject to replacement by secondary minerals (epidote, chlorite, hydromicas, oxides and hydroxides of Fe-Mn, mixed-layered and clayey minerals). The latter possess high sorption properties in relation to radionuclides, and therefore "heal" porosity and microcracks in rocks because they occupy a greater part of the volume than did the primary minerals.

Because of the relatively small dimensions of potential sites $(1.5-3 \mathrm{~km})$ scattered over the special studies zone, it will be impossible to position the complex of engineering facilities necessary for construction of a shaft-type and mined cavity repository. Mayak could utilize its previous experience in the disposal of RW in wells of large $(>600 \mathrm{~mm})$ diameter. Considering the peculiarities in geological structure and distribution of volcanogenic rocks, the most optimal level for the proposed repository at Mayak is a depth interval of 500-1000 $\mathrm{m}$ in which it is possible to dependably isolate the Cs-Sr fraction for 500-1000 years. More study is required to identify possible depths for immobilized Pu-containing wastes. Three potential sites in less disturbed blocks will receive further, more detailed examination to identify the optimal site for construction of an underground laboratory and, subsequently, the radioactive waste repository (Fig. 4).

LLNL has been actively and continuously engaged in Russian geologic disposal activities since 1995. LLNL is prepared to work with VNIPIPT and KRI, many other RF organizations and others to make an official RF geologic program become a major activity within the RF. A geologic repository program is worthy of an undertaking and the RF experts are qualified and ready to begin immediately when funds are available. LLNL is positioned to provide technical assistance to make such program be rapidly and effectively implemented.

\section{B. Mayak Technical Papers and Reports (Appendix C)}

Additional information about potential repository sites near Mayak may be found in the following papers and reports, which are reprinted in full as Appendix $\mathrm{C}$ of this document:

C.1 V. I. Velichkin, IGEM-RAS, "Status of Geologic Repository Site Investigations at the Mayak Territory," Immobilization of Excess Weapons Plutonium in Russia: A Review of LLNL Contract Work: Lawrence Livermore National Laboratory, Livermore, CA, UCRL-JC-143846, pp. 141-144, 2001.

C.2 T. A. Gupalo, V. L. Milovidov, V. E. Perovsky, VNIPIPT, "Evaluation of Sites Studied for Disposal of Plutoniumcontaining Wastes at PA Mayak in terms of Geological, Ecological, and Production Factors," Immobilization of Excess Weapons Plutonium in Russia: A Review of LLNL Contract Work, Lawrence Livermore National Laboratory, Livermore, CA, UCRL-JC143846, pp. 145-151, 2001. 


\section{FINAL REMARKS}

For any country, a radioactive waste geologic isolation problem is of a multi-faceted nature that needs long-term scientific, research, design and survey, and site characterization activities; reliable substantiation of site suitability; and strict procedures for decision making. Many of these tasks have been studied in recent years in detail in joint Russian-American investigations on immobilization and geologic isolation of weapons plutonium-containing radioactive production wastes. The draft plans and proposed programs for scientific research activities for site characterizations on the justification of the site selection and suitability for the disposal of HLW and $\mathrm{Pu}$-containing materials, reliability assessments of decisions, optimization of engineered barriers and technology have been identified for the Mayak and K-26 sites [3, 24]. The only cause of delay in realizing the site selection, engineering design, and completion of the underground laboratories is a lack of financing. The plans and the technical RF expert staff exist to undertake such an assignment.

Taking into account the level of completed scientific studies, the professional degrees and experience of the RF staff, and the existence in Russia of unique places for scientific, technological, and methodological investigations, it would be invaluable to join and integrate these efforts with those of other countries to implement and resolve the required tasks to safely geologically isolate radioactive wastes and plutonium-containing wastes in a geologic repository. Such an endeavor is truly of multinational interest.

The following near-term activities need to be carried out at Mayak and the MCC sites to bring to fruition the development of a geologic repository in Russia.

- Develop further definition and details in current RF plans and obtain approval of the engineering surveys and a site characterization activities program, so as to justify the investments in the development of underground laboratories;

- Conduct comprehensive surface geophysical studies;

- Perform deep drilling of boreholes at the screened sites, including detailed geophysical and hydrogeological studies of the rock masses;

- Review comprehensively and interpret all existing data on the studies by various RF organizations and agencies required for the draft "Declaration of Intent" for construction of an underground laboratory;

- Develop, prepare, and document a "Declaration of Intent" for construction of an underground laboratory; and obtain its approval with the related RF agencies;

- Obtain official RF approval of the screened and selected sites at the Krasnoyarsk and Mayak sites for further development, including an agreement to proceed with required environmental agencies;

- Optimize engineered geologic disposal concepts and conduct the long-term safety analyses, computer modeling and performance assessment methods for Russian geologic disposal. 


\section{REFERENCES}

1. L. J. Jardine, T. A. Gupalo, et al., US-Russian Joint Study Report of Geologic Disposition Options for Excess Plutonium from Dismantled Nuclear Weapons (Combined Report), September 30, 1996 (UCRL-ID-124711); Joint United States Russian Plutonium Disposition Study Summary Report, September 1996.

2. T. A. Gupalo, Large-Scale Laboratory and In-Situ Investigations of Pu and U Radionuclides Migration in the Multi-Barrier System for Underground Isolation of the MCC Vitrified Waste, Final Report, RP \#215, (B512134), December, 2001.

3. L. J. Jardine, T. A. Gupalo, Geologic Repository Plan for Disposal of Plutonium-Containing and Other Radioactive Materials in Russian Industrial Sites, (B512155), UCRL-CR-146982, Lawrence Livermore National Laboratory, Livermore, CA, February 2002.

4. E. B. Anderson, Plan for Geologic Repositories for Disposal of Immobilized Plutonium-containing Materials and Other Radioactive Materials at Russian Industrial Sites, Final Report RP-188 (B512154), August, 2001.

5. K. G. Kudinov et al., Engineering Feasibility Study for Krasnoyarsk-26 Plutonium Sludges, Final Report, RP-95, Task Agreement B347676 under Master Task Agreement B333685, 1999.

6. K. G. Kudinov et al., Declaration of Intent for Krasnoyarsk-26 Plutonium Sludges, Technical Report--Final Declaration of Intent (DOI), RP-118 (Task Agreement B506210 under Master Task Agreement B333685), 2000.

7. K. G. Kudinov et al., MCC Engineering Reports (compilation of RP-199, -204, -205, -206), B506233, Justification of Investment, Task 1, Progress Report, RP-231, February 2002.

8. S. I. Rovney et al., Mayak VNIPIET Engineering Report for the TEF (B506208), March 2002, RP-232.

9. T.A. Gupalo, Development of Quantitative Criteria for Suitability of Rock Mass for Safe Long-term Storage of Waste from Weapons Plutonium Production, Project 307B Final Report (RP-227), Feb. 28, 2001.

10. E. B. Anderson, Investigations in the field of long-lived radioactive waste final disposal in geological formations : an assessment of the possibility of the RT-2 plant radioactive waste disposal in rocks of the Yenisey Ridge, Project 255 Final Technical Report of ISTC 255-95, RP-226, January 2002.

11. E. B. Anderson, Geological-Geochemical and Geophysical Research of Granitoids of the Nizhnekanskiy Massiffor a Choice of Sites for Underground Repository of High-Level Radioactive Waste of Russian Industrial Sites: Mining-Chemical Combine (MCC), "Mayak" Production Association, Siberian Chemical Combine (Tomsk), Work Plan 1491, ISTC Project Proposal \#1491, RP-229, January 2002.

12. T. A. Gupalo, Development of A Comprehensive Plan for Scientific Research, Exploration, and Design: Creation of An Underground Radioactive Waste Isolation Facility at The Nizhnekansky Rock Massif, ISTC Project Proposal \#2377, RP228, January 2002.

13. T. A. Gupalo, E. B. Anderson and L. J. Jardine, "Status of Geologic Disposal and Isolation in Russia for PlutoniumContaining Wastes of Military Programs," DISTEC 2000 Conference, Berlin, Germany, September 4-6, 2000, Lawrence Livermore National Laboratory, UCRL-JC-138202, 2000.

14. A. I. Rybalchenko, M. K. Pimenov, Deep Disposal of Liquid Radioactive Wastes, Publishing house AT (in Russian), 1994.

15. E. G. Dzekun, Yu. V. Glagolenko, E. G. Drojko, et al., "Industrial Scale-Plant for HLW Partitioning in Russia," Proc. Int. Top. Meet. on Nucl. and Hazard Waste Man. Spectrum'96, Seattle, Amer. Nucl. Soc., pp. 2138-2139, 1996.

16. N. N. Melnikov, V. P. Konukhin, V. N. Komlev, "Underground Disposal of Radioactive Wastes," Apatity, Kola Branch, Rus. Acad. Sci., 214 p. (in Russian), 1994.

17. E. B. Anderson, S. L. Shabalev, G. G. Savonenkov, E. F. Lyubiseva, "Investigations of the Nizhnekansky granitoid massif (Middle Siberia, Russia) as a promising territory for deep geological disposal of HLW," Proc. Intl. Conf. On Rad. Waste Disposal, DisTec'98, Hamburg, Germany, pp. 105-110, 1998.

18. N. P. Laverov, V. I. Velichkin, B. I. Omelyanenko, V. A. Petrov, and N.N. Tarasov, "New Approaches to the Underground Disposal of HLW in Russia," Radioactive Waste Management and Environmental Remediation, ASME, 1999.

19. Yu. V. Glagolenko, E. G. Dzekun, E. G. Drojko, G. M. Medvedev, S. I. Rovny, A. P. Suslov, "Strategy of Radioactive Waste Management at the Production Association 'Mayak'," Voprosy Radiatsionnoi Bezopasnosti Journal (Radiation Safety Issues), 2, pp. 3-10 (in Russian), 1996.

20. Yu. V. Glagolenko, E. G. Dzekun, S. I. Rovny, V. K. Sazhnov, V. P. Ufimcev, V. S. Eroshevicky, G. A. Laptev, V. I. Osnovin, B. S. Zakharkin, V. S. Smelov, B. V. Nikipelov, "The Processing of Spent Nuclear Fuel on RT-I Complex: 
History, Problems, Perspectives," Voprosy Radiatsionnoi Bezopasnosti Journal (Radiation Safety Issues), 2, pp. 3-12 (in Russian), 1997.

21. O. L. Kedrovsky, I. Yu. Shischitz, T. A. Gupalo, "Substantiation of High-Level Radioactive Waste and Spent Nuclear Fuel Conditions of Localization in geologic Formations", Atomnaya Energiya Journal (Atomic Energy), 70, 5, pp. $294-297$ (in Russian), 1991.

22. V. L. Milovidov, V. I. Ryzhenkov, O. A. Prokopova, "Mathematical Processing of the Results of Geologic and Hydrogeological Investigations", Spetsialnye Voprosy Atomnoy Nauki i Tekhniki: Geologia i Gornoye Delo Journal (Specific Issued of Nuclear Science and Technology: Geology and Mining), 1, pp. 45-48 (in Russian), 1989.

23. A. X. Sysoev, V. A. Petrov, I. A. Ivanov, A. B. Volkov, "Geomorphological and Tectonophysical Approach to the Identification of Sites for Radioactive Waste Disposal at the PA Mayak Territory, Russia," Radioactive Waste Management. and Environmental. Remediation, ASME, 1999.

24. L. J. Jardine, Framing a Bilateral U.S.-Russian Geologic Repository Initiative, UCRL-ID-131801, Lawrence Livermore National Laboratory, Livermore, CA, 1998.

25. L. J. Jardine, K. G. Kudinov, A. A. Tretyakov, V. V. Bondin, Yu. P. Sorokin, L. F. Manakova, A. A. Shvedov, A. S. Aloy, G. B. Borisov, T. A. Gupalo, "Processing of the MCC K26 Plutonium-Bearing Sludges To Recover Weapons-Grade Plutonium That Is Not Under Any Treaty Or Monitoring Agreement, "Waste Management 2002, Tucson, AZ, Feb. 24-28, 2002, UCRL-JC-145333, Lawrence Livermore National Laboratory, Livermore, CA, 2002.

26. L. J. Jardine, G. B. Borisov, S. I. Rovny, K. G. Kudinov, A. A. Shvedov, "An Opportunity to Immobilize 1.6 MT or More of Weapons-Grade Plutonium at the Mayak and Krasnoyarsk-26 Sites," 8th International Conference on Radioactive Waste Management and Environmental Remediation, Bruges, Belgium, Sept. 30-Oct. 4, 2001, UCRL-JC-141849, Lawrence Livermore National Laboratory, Livermore, CA 2001. 


\section{APPENDICES}

\section{Appendix A: Overview, Policy and Planning Documents for RF Repository}

A.1 L. J. Jardine, T. A. Gupalo, Geologic Repository Plan for Disposal of Plutonium-Containing and Other Radioactive Materials in Russian Industrial Sites, (B512155), UCRL-CR-146982, Lawrence Livermore National Laboratory, Livermore, CA, February 2002.

A.2. L. J. Jardine, T. A. Gupalo, et al., US-Russian Joint Study Report of Geologic Disposition Options for Excess Plutonium from Dismantled Nuclear Weapons (Combined Report), September 30, 1996 (UCRL-ID-124711); Joint United States Russian Plutonium Disposition Study Summary Report, September 1996.

A.3 L. J. Jardine, Framing a Bilateral U.S.-Russian Geologic Repository Initiative, Lawrence Livermore National Laboratory, Livermore, CA, UCRL-ID-131801, 1998.

A.4 T. A. Gupalo, E. B. Anderson and L. J. Jardine, Status of Geologic Disposal and Isolation in Russia for PlutoniumContaining Wastes of Military Programs, DISTEC 2000 Conference, Berlin, Germany, September 4-6, 2000 (UCRL-JC138202).

A.5 L. J. Jardine, C. F. Smith, W. G. Halsey; Vision and Framework for Technical and Management Support to Facilitate Foreign Spent Fuel Storage and Geologic Disposal in Russia, UCRL-ID-134762, July, 1999.

A.6 L. J. Jardine., W. G. Halsey, and C.F. Smith, "Foreign Spent Fuel Storage and Geologic Disposal in Russia: A Technical Path Forward," Waste Management 2000, Tucson, AZ, Feb. 27, 2000, UCRL-VG-137265, 2000.

A.7 W. G. Halsey, L. J. Jardine and C. E. Walter, “Disposition of Plutonium in Deep Boreholes,” Proceedings of NATO International Scientific Exchange Program, Advanced Research Workshop on Disposal of Weapons Plutonium - Approaches and Prospects, St. Petersburg, Russia, May 14-17, 1995, Lawrence Livermore National Laboratory, UCRL-JC-120995, R1, 1995.

A.8 T. A. Gupalo, V. P. Beygul, R. T. Islamov, "Safety Problems for Long-term Underground Storage and Final Disposal of Nuclear Materials," Advanced Research Workshop: Nuclear Materials Safety, June 8-10, 1998, St. Petersburg, Russia, Lawrence Livermore National Laboratory, UCRL-JC-132632, p. 73, January 4, 1999.

A.9 W. G. Halsey and L. J. Jardine, Russian Spent Fuel Storage and Transportation to Support Termination of Civil Power Reactor Fuel Reprocessing at RT-1, A Technology Map, Lawrence Livermore National Laboratory, UCRL-ID-142749-DR, March 5, 2001.

\section{Appendix B: K-26 Technical Papers and Reports}

B.1 E. Anderson, Investigations in the field of long-lived radioactive waste final disposal in geological formations : an assessment of the possibility of the RT-2 plant radioactive waste disposal in rocks of the Yenisey Ridge, Project 255 Final Technical Report of ISTC 255-95, RP-226, January 2002.

B.2 T. A. Gupalo, Development of quantitative criteria for suitability of rock mass for safe long-term storage of waste from weapons-grade plutonium production, illustrated by Krasnoyarsk Mining Chemical Combine: Summary Technical Report 307B, (RP-227), Feb. 28. 2001.

B.3 E. B. Anderson, Geological-Geochemical and Geophysical Research of Granitoids of the Nizhnekanskiy Massif for a Choice of Sites for Underground Repository of High-Level Radioactive Waste of Russian Industrial Sites: Mining-Chemical Combine (MCC), "Mayak" Production Association, Siberian Chemical Combine (Tomsk), Work Plan 1491, ISTC Project Proposal \#1491, RP-229, January 2002.

B.4 T. A. Gupalo, Development of A Comprehensive Plan for Scientific Research, Exploration, and Design: Creation of An Underground Radioactive Waste Isolation Facility at The Nizhnekansky Rock Massif, ISTC Project Proposal \#2377 Section 1. Concurrence and Commitments, RP-228, January 2002.

B.5 E. Anderson, Plan for Geologic Repositories for Disposal of Immobilized Plutonium-containing Materials and Other Radioactive Materials at Russian Industrial Sites, final report RP-188 (B512154), August, 2001.

B.6 T. A. Gupalo, Large-Scale Laboratory and In-Situ Investigations of Pu and U Radionuclides Migration in the MultiBarrier System for Underground Isolation of the MCC Vitrified Waste, Final Report, RP-215, (B512134), December, 2001.

B.7 T.A. Gupalo, V. P. Beygul, VNIPIPT, "Description of Engineering Solutions for Safe Underground Isolation of MCC Immobilized Sludges for JOI," Immobilization of Excess Weapons Plutonium in Russia: A Review of LLNL Contract Work: UCRL-JC-143846, pp. 75-80. 
B.8 V. S. Gupalo, VNIPIPT, "Results of Studies on Mining and Geological Conditions and Mathematical Modeling of Geomechanical Processes in Underground Storage Facilities for MCC Immobilized Sludges from KMCC," Immobilization of Excess Weapons Plutonium in Russia: A Review of LLNL Contract Work: UCRL-JC-143846, pp. 81-90.

B.9 T.A. Gupalo, V. P. Beygul, VNIPIPT; K. G. Kudinov, MCC; L. J. Jardine, LLNL, "General Concept and Content of VNIPIPT Works on Substantiation of Geological Isolation of Pu-containing Immobilized Waste," Immobilization of Excess Weapons Plutonium in Russia: A Review of LLNL Contract Work: UCRL-JC-143846, pp. 235-238.

B.10 T.A. Gupalo, V. P. Beygul, S. L. Speshilov, VNIPIPT; A. A. Tretyakov, S. A. Manakova, KMCC, "Investigation of Uranium and Plutonium Migration in the Multi-barrier System for Underground Isolation of Vitrified Wastes from KMCC," Immobilization of Excess Weapons Plutonium in Russia: A Review of LLNL Contract Work: UCRL-JC-143846, pp. 239-246.

B.11 E. B. Anderson, V. G. Savonenkov, S. S. Shabalev, E. F. Lyubtseva, Yu. M. Rogozin, KRI, "Site Selection for HLW Geological Disposal at the Nizhnekansky Granitoid Massif," Immobilization of Excess Weapons Plutonium in Russia: A Review of LLNL Contract Work: UCRL-JC-143846, pp. 247-250

B.12 T.A. Gupalo, A. N. Titkov, VNIPIPT, "Sequence of Works Aimed at Selection of a Site for Plutonium-containing Waste Disposal at Nizhnekansky Massif," Immobilization of Excess Weapons Plutonium in Russia: A Review of LLNL Contract Work: UCRL-JC-143846, pp. 251-252.

B.13 T.A. Gupalo, V. L. Milovidov, VNIPIPT, "Preliminary Substantiation of Site Selection in Nizhnekansky Massif for Underground Disposal of MCC Pu-containing Wastes by Standards for RW Underground Storage Facility Designing and Construction," Immobilization of Excess Weapons Plutonium in Russia: A Review of LLNL Contract Work: UCRL-JC-143846, pp. 253-257.

B.14 T. A. Gupalo, VNIPIPT, "Summary of Plutonium Sorption on Rocks and Materials of Destruction of Engineered Barriers at Normal Pressure and Elevated Temperature [UTA-331]," Excess Weapons Plutonium Immobilization in Russia: A Review of LLNL Contract Work, Lawrence Livermore National Laboratory, Livermore, CA, UCRL-ID-138361, pp. 197-200.

B.15 T. A. Gupalo, VNIPIPT, "Summary of Plutonium Sorption-Desorption on Rock Samples at Elevated Pressure and Temperature [B338273]," Excess Weapons Plutonium Immobilization in Russia: A Review of LLNL Contract Work, Lawrence Livermore National Laboratory, Livermore, CA, UCRL-ID-138361, pp. 201-206.

B.16 V. Beygul, VNIPIPT, "Comparison of K-26 Glass Properties and Plutonium Sorption on Hard Rock Cores at Elevated Temperature and Pressure [B501120]," Excess Weapons Plutonium Immobilization in Russia: A Review of LLNL Contract Work, Lawrence Livermore National Laboratory, Livermore, CA, UCRL-ID-138361, pp. 207-214.

B.17 E. Zakharova, RAS, "Laboratory Studies on the Behavior of Plutonium in the Solidified Radioactive Waste Repositories Located in the Low Fractured Rock Masses [B338272, B501120]," Excess Weapons Plutonium Immobilization in Russia: A Review of LLNL Contract Work, Lawrence Livermore National Laboratory, Livermore, CA, UCRL-ID-138361, pp. 215-227.

\section{Appendix C: Mayak Technical Papers and Reports}

C.1 V. I. Velichkin, IGEM-RAS, "Status of Geologic Repository Site Investigations at the Mayak Territory," Immobilization of Excess Weapons Plutonium in Russia: A Review of LLNL Contract Work: Lawrence Livermore National Laboratory, Livermore, CA, UCRL-JC-143846, pp. 141-144.

C.2 T. A. Gupalo, V. L. Milovidov, V. E. Perovsky, VNIPIPT, "Evaluation of Sites Studied for Disposal of Plutoniumcontaining Wastes at PA Mayak in terms of Geological, Ecological, and Production Factors," Immobilization of Excess Weapons Plutonium in Russia: A Review of LLNL Contract Work, Lawrence Livermore National Laboratory, Livermore, CA, UCRL-JC143846, pp. 145-151. 